\title{
West Nile Virus: Characteristics of an African Virus Adapting to the Third Millennium World
}

\author{
Marina Monini ${ }^{1}$, Emiliana Falcone ${ }^{1}$, Luca Busani ${ }^{1}$, Roberto Romi ${ }^{2}$ and Franco Maria Ruggeri ${ }^{*}, 1$ \\ ${ }^{I}$ Dipartimento di Sanità Pubblica Veterinaria e Sicurezza Alimentare, and ${ }^{2}$ Dipartimento di Malattie Infettive, \\ Parassitarie e Immuno-mediate, Istituto Superiore di Sanità, V.le Regina Elena, 299 - 00161 Rome, Italy
}

\begin{abstract}
The emergence and spread of West Nile Virus (WNV) from North through South America during the last decade, and the recent outbreaks of disease in both humans and horses in Europe suggest that the epidemiology of this infection is evolving. WNV is now considered among the emerging threats for both human and veterinary public health in areas like Europe where it was previously regarded to as an exotic agent. Further knowledge has built up from studies investigating the characteristics of the virus and its genome evolution capacity, the adaptation to new avian host species, the changes in vector competence and biology, and the host-pathogen interactions, including the immune response. Also, the new needs for preparedness to future major outbursts of disease have stimulated research on virus detection and characterization, filling the gaps in both specialized diagnostic technology and the need for field rapid assays. This review will present an overview of WNV virology, remarking the impact of virus diversity and evolution on theoretical and practical aspects involved in both risk definition, detection and control of infection.
\end{abstract}

Keywords: West Nile Virus, flavivirus, zoonosis, genome, evolution, immunity, virulence.

\section{INTRODUCTION}

West Nile Virus (WNV) is a member of the genus Flavivirus, in the family Flaviviridae, transmitted mainly by mosquito bites [1].

After its first isolation in 1937 from the blood of a febrile patient in the West Nile Province in Uganda [2], WNV has not been regarded as a significant pathogen, because most of the cases were asymptomatic, and humans and animals were considered as accidental dead-end hosts. In the following decades, sporadic outbreaks of WNV infection associated with encephalitis and death have been reported in Israel (1950s) [3], France (1962-1963) [1], South Africa (1974) and India (1980/1981) [4], but only after the severe human outbreak occurring in Romania in 1996 [5], WNV infection has become a major public health and veterinarian concern in Europe and in the Mediterranean basin.

In contrast with the picture observed in Europe, with occasional incursions and localized activity in areas with favorable conditions, a very different pattern was seen in the Western Hemisphere, where WNV unexpectedly emerged in 1999 in the district of New York, with encephalitis reported in humans and horses $[6,7]$. In the following years, the virus was actor of a considerable spread across the United States, Canada, Central and South America. Until now, WNV activity has been reported in humans, birds, animals or mosquitoes from all states except Hawaii, Alaska, and Oregon, so that WNV can be considered one of the most widely distributed of the flaviviruses.

*Address correspondence to this author at the Dipartimento di Sanità Pubblica Veterinaria e Sicurezza Alimentare, Istituto Superiore di Sanità, V.le Regina Elena, 299, 00161 Rome, Italy; Tel: +390649902980; Fax: +390649387077; E-mail: franco.ruggeri@iss.it
The WNV capability to cause either limited outbreaks or wide epidemics seems to be related to the genetic characteristics of different viruses. All of the major outbreaks of human encephalitis have been associated with WNV strains genetically classified as lineage 1, establishing an important correlation between viral genetics and disease phenotype. The WNV transmission and maintenance are strictly related to the presence of competent vectors (ornithophilic mosquito species) and avian hosts that maintain sufficient viremia for the infection of subsequent mosquitoes. Also other animal species show the capability to develop sufficient viremia for infection of mosquito vectors, but the role that these hosts play in the transmission dynamics of WNV is still unclear, albeit of significant interest. Humans and equines normally fail to generate sufficiently high viremic titers for the infection of mosquito hosts and are considered "dead end" hosts.

The aim of this review is to discuss virus characteristics, virus interaction with vectors and hosts, including the immune response, at the light of the potential spread and endemicity of WNV in EU.

\section{THE VIRUS AND ITS GENOME}

West Nile virus is a mosquito-transmitted Flavivirus. The genus Flavivirus consists of nearly 80 different viruses, many of which are arthropod-borne human pathogens [8]. WNV is a member of the Japanese encephalitis (JE) complex that includes St. Louis encephalitis (SLE), Murray Valley encephalitis (MVE), and the Kunjin (KUN) viruses [9], in the family Flaviviridae.

WNV is a spherical particle of approximately $50 \mathrm{~nm}$ in diameter: the lipid bilayer membrane, derived from the host cell, surrounds a nucleocapsid core containing a single stranded RNA genome of about 11 kilobases in length flanked by $5^{\prime}$ - and 3'-untranslated regions, which have 
secondary structures necessary for the initiation of translation and for replication [8]. The genome is packaged with the viral capsid protein (C) into a host-derived lipid bilayer in which 180 copies of the envelope protein (E) are embedded [10]. The RNA genome carries a 5' cap at the 5' end, and lacks a polyadenylated tail at the 3' end. The genomic RNA corresponds to the messenger RNA for the translation of a single long open reading frame into one large polyprotein that is processed co- and post-translationally, by a virally encoded serine protease and multiple host proteinases, into three viral structural proteins $(\mathrm{C}$, pre- $\mathrm{M}$ and E) and seven non-structural (NS) proteins (NS1, NS2a, NS2 b, NS3, NS4a, NS4b, NS5). Surrounding the ORF are 5' and 3' non coding regions (NCRs) of around 100 nucleotides (nt) and 400-700 nt respectively [8]. Understanding of the viral replication cycle is still far from being complete. Virions bind and enter cells via receptor-mediated endocytosis specific for viral envelope proteins [8]. A structural reorganization of the $\mathrm{E}$ protein delivers the nucleocapsid and viral RNA into the cytoplasm where the genome is translated [11]. Viral proteins are processed from the single polyprotein of approximately 3000 amino acids by cellular and viral proteases. Following RNA replication within the cytoplasmic replication complexes, progeny virions assemble by budding through intracellular membranes of the rough endoplasmic reticulum. Once transported through the host secretory pathway, the mature virions are released into the cytoplasm, fused with the plasmatic membrane and finally are released by exocytosis into the extracellular compartment $[8,11]$.

Studies of the phylogenetic relatedness on nucleic acid sequence data corresponding to a 255-bp region of the $\mathrm{E}$ glycoprotein gene of WNV strains isolated in different geographic regions, demonstrated that WNV isolates fall into two major genetic lineages diverging by 25 to $30 \%$ nucleotide differences [12,13] and several subclades or clusters [7, 12, 14-16]. Lineage 1 is composed of WNV strains with a broad geographical distribution ranging from West Africa to the Middle East, Eastern Europe, North America, and Australia. This latter lineage includes viral strains with great nucleotide sequence homology, which account for the recent outbreaks in human, horses and birds. Lineage 1 can be further subdivided into at least three more clades. Clade 1a contains strains from Europe, Middle East, Asia, Africa and America, and presents different clusters including: (i) the most recent Israeli/American virus strains collected between 1997 and 2000; (ii) the strains isolated in Europe and Russia between 1996 and 2000 (Romania/19967, Russia 1999, and France/2000) [14], and (iii) the two closely related Italian 1998 and 2008 WNV strains [17]. A human WNV strain isolated in Italy in 2009 from an asymptomatic individual resident in Rovigo province also belongs to lineage 1 , clade $1 \mathrm{a}$, and is closely related to the two WNV strains isolated from magpies in Italy in 2008 [18]. In addition to those mentioned above, two more clusters have been identified, one including the strains isolated in the 1980s in Central African Republic, the other including the Egyptian strain of 1951 and the Romanian1996 human strain.

Within clade $1 \mathrm{~b}$, highly homologous strains isolated in Australia from 1960 to 1994 [16, 19] can be grouped. This clade also includes the Australian (Kunjin) strains isolated from 1960 to 1994 [16], that can be distinguished from other lineage $1 \mathrm{WNV}$ viruses by monoclonal antibody binding and cross-neutralization analysis $[7,15]$. According to Lanciotti et al. [13], clade 1c contains Indian WNV isolates collected between 1955 and 1980, but this finding was not confirmed in following studies [14]. These viruses can also be distinguished from other lineage 1 viruses by serological assays [20].

WNV strains from the northeastern United States and Israel are closely related, sharing $99.7 \%$ nucleotide sequence homology and grouping in a unique subclade within clade 1a. This high degree of sequence identity between US and Israel WNV strains support the hypothesis that the US WNV strains originated from the Middle East [7].

Lineage 2 contains the B 956 prototype strain and other strains isolated exclusively in the sub-Saharan Africa and Madagascar [7, 12, 15].

Recently, additional lineages have been proposed for viruses that exhibit considerable genetic differences from the two already existing [21]: lineage 3 including a virus strain (Rabensburg virus) isolated in central Europe (Czech Republic), lineage 4 enclosing a unique virus isolated in the Caucasus [22]. These last two viruses, however, may also be considered independent flaviviruses within the Japanese encephalitis group [22]. Finally, a fifth lineage was suggested for a West Nile virus strain isolated in India [23]. Grouping of isolates based on phylogenetic analysis does not correlate with the geographical distribution of the virus, demonstrating the fundamental importance of migrating birds in viral spread dynamics [12].

The recent outbreaks associated with severe humans and avian diseases have all been caused by a subset of strains in lineage 1 . In contrast, lineage 2 strains appear to be less virulent for humans, as they have been isolated from asymptomatic or mild cases or even during search for other pathogens [13].

\section{WNV DETECTION}

The large epidemics and epizootics occurred in the US have considerably contributed to the improvement in WNV diagnosis in both humans and animals, focusing in the detection of either viruses or anti-WNV antibodies (Ab). Owing to the following enhanced surveillance programs, large collections of human and animal sera have been accumulated. The main difficulties in $\mathrm{WN}$ disease diagnosis are the requirement for level 3 safety labs, the necessity for a multi-species testing and for specific diagnosis that can overcome the cross-reactivity with other flaviviruses [24].

The election method for WNV detection in vertebrate, mosquito pools and avian samples remains viral isolation which can be performed from cerebrospinal fluid (CSF), blood or tissues in infected cell cultures, even though this technique requires good quality samples [25].

Antibody testing in patients or animal sera is of large usefulness for diagnosing WNV infection, both in the course of large field studies or screening and when samples are taken in absence of or late after symptomatic phase. Serological testing is mainly based on detection of anti-E protein antibodies, although the cross-reactivity of the neutralizing antibodies response against flaviviruses limits 
the specificity of the tests. This is particularly true in areas where other Flaviviridae are concomitantly spread [26, 27]. The plaque reduction neutralization test (PRNT) detecting WNV specific neutralizing antibodies in CSF and serum remains the assay required for confirmation of flavivirus infections and identification of the infecting agent [28], although paired serum samples are needed to confirm seroconversion.

Infected cell culture supernatants or preparations from WNV infected suckling mouse brains (SMB) are antigens classically used for WNV serodiagnosis. Alternatively, recombinant antigens such as the envelope glycoprotein $\mathrm{E}$ [29], virus-like particles (VLP) [30], or the non-structural NS1 [31], NS3 and NS5 [32] proteins may presently be produced and purified in large scale for use in different assay formats in the absence of particular containment facilities. The IgM capture enzyme-linked immunosorbent assay (ELISA) on serum or CSF is widely used for diagnosis of WNV in humans in the United States [33]. In addition, a series of immunological tests (from different ELISA formats to Western blotting to Solid-phase dot-ELISA technology) is in use in several laboratories for both human and animal diagnostics worldwide [34-36]. However, these tests are laborious, time-consuming, and sometimes need to be conducted in level 3 biosafety laboratories [24].

Further exploitation of sensitive and specific assays for prompt differential diagnosis of WNV infection in either humans and animals in the field is still needed and may take advantage of modern knowledge of WNV antigen determinants, recombinant DNA and protein technology, and methods for production of MAbs with different affinity [37, 38]. As for other viruses, major expectations are laid in the field of genome testing approaches by conventional, nested or real-time RT-PCR, which are enormously faster than cultivation methods and can be adjusted for use in clinical and epidemiological applications [28, 39-41].

Single-tube real-time RT-PCR, which can be performed on RNA extracted from a wide variety of tissues in all infected animal species, shows many advantages compared to end-point RT-PCR because it is more rapid, often more sensitive, more specific, and minimizes contamination [28]. In addition, together with an automated RNA extraction, real-time RT-PCR can be used in large-scale surveillance, and allows quantitative measurement of viral nucleic acids [42]. In several studies, molecular detection assays based on broadly reactive (degenerate) primers may be used for the simultaneous detection and quantification of distinct flaviviruses using species-specific and group-specific primers in a single reaction [40] or targeting the flavivirus consensus amplimers located at the RNA-dependent RNA polymerase domain of the NS5 protein [43].

Various approaches for screening of WNV and viral antibodies in blood, body fluids and other tissues have been developed and used as routine screening tools for blood donation and cell tissues/organs transplantations over the last several years [44]. Despite implementation of nucleic acid testing, particularly by real-time RT-PCR, WNV transmission through blood transfusion and organ transplant still occurs, thus remarking sensitivity limits of the present screening assays, particularly on mini-pool samples $[45,46]$. Individual donation testing for WNV blood screening is more sensitive, but presents an unfavourable costeffectiveness [47].

Although more advanced than for other arboviruses, molecular methods for WNV detection still have wide margins for technical implementation to both adapt their use to the variety of clinical samples (tissue, blood or CSF) from humans and animals, and particularly vector tissue extracts [48-50], and to take into account more recent knowledge from sequence analysis of strains circulating and evolving in various geographical areas and habitats. Problems are also related to the very low viral loads that can be expected especially in post-mortem tissues or while screening subjects in the absence of symptoms. Similar to antigen-antibody based detection assays, efforts are also needed for molecular approaches to overcome the problems posed by the occasionally close similarity of nucleotide sequences between different members of Flaviviridae when a genusspecific diagnosis is required [48, 51,52]. Although suited for a rapid and sensitive diagnosis at the experienced lab level, molecular methods are hardly usable for local field investigations particularly on outdoor animals or farms, where development of user-friendly antigen-based field test would be desirable.

\section{WNV, RESERVOIRS AND VECTORS}

According to the existing literature, ornithophilic (birdfeeding species) mosquitoes are commonly considered as the principal vectors of West Nile virus [5]. In particular, the vector species mainly involved in WNV transmission to humans are Culex pipiens Linneus 1758, the widespread common mosquito in the northern hemisphere, and its vicariant species $C x$. quinquefasciatus Say 1823, in the southern hemisphere.

Nevertheless, little is known about the factors that may influence the epidemiological cycle of the disease, that may assume different characteristic depending on the type of environment (rural, urban, etc.). WNV is taken up by a competent ornithophilic mosquito vector, during blood feeding on an infected bird [53]. After a short period necessary to the replication of the virus, the infected mosquito will spread WNV biting the main hosts (migratory or indigenous birds, which also act as a reservoir), and/or horses or humans, which are "incidental dead-end" hosts [54].

Overall, the epidemiological cycle of WNV in temperate areas may be divided in two different moments $[55,56]$ :

1) A rural/wild cycle, that involves migratory and indigenous birds (such as white storks and pigeons, respectively), and one or more ornithophilic mosquito species such as Culex univittatus (Africa, Middle East), Cx. tarsalis (East Europe), Cx. pipiens restuans (USA) Cx. Modestus (France, Russia), and that is known as "enzootic" (or exoanthropic) cycle. Characteristic environments where the wild cycle commonly occurs are wetlands, river deltas and flooded plains that migratory birds choose for nesting, coming in contact with the potential mosquito vectors breeding in the same area.

2) An urban, synanthropic cycle that involves domestic birds, such as chicken, house sparrows and pigeons, 
and a mosquito species that feed on both humans and birds, such as Culex pipiens/molestus. This cycle is named "epizootic" [57,58], and may occurs also in urban areas when human activities make available a number of breeding sites for mosquito populations, as happened in Bucharest, Romania, and in the US [5-7].

Depending on the kind of environment, the abundance of mosquito species and on their degree of competence for WNV transmission, two main hypotheses about competence of the vectors have been formulated [59]: (i) in the former, the enzootic cycle is sustained by one or more mosquito species, mainly ornytophilic, which ensure WNV transfer from migratory to indigenous birds, allowing the dissemination and amplification of the virus. Different species, with a broader range of hosts and anthropophagic, will act as a "bridge" vector, between infected birds and horses/humans; (ii) alternatively, a single species able to bite birds as well as mammals may act as both enzootic and epizootic vector.

In both hypotheses, the species with a broad range of host could in fact be $C x$. pipiens.

A number of factors are involved in WNV vector competence. Firstly the vector must be genetically susceptible to become infected with WNV and supportive of its replication, and secondly, the vector must be able to transmit it to the natural host. For these reasons, the virus isolation in a field-collected mosquito does not necessarily imply competence to transmit it [60-65]. Under laboratory conditions, all of common species of the genus Culex may become infected, as well as other species belonging to different genera (i.e. Aedes, Ochlerotatus, Culiseta, Coquillettidia). Up to date, more than 70 species of mosquitoes have been found to be naturally infected with WNV worldwide, but their possible involvement in the epidemiology of the disease is probably negligible in most cases. Some concern is only related to the high competence showed by Ae. albopictus and Oc. japonicus, two species highly anthropophilic which may sustain and amplify the infection in the urban areas $[59,61]$.

In the last years, WNV has been circulating in various European countries. Particularly, in Italy infection has quickly spread at least through five neighboring regions in 2008-2009 [17, 66, 67]. This outbreak followed the earlier significant outbreak of 1998, occurred in Tuscany only among horses [68].

The entomological inquiries carried out after these events, a 3-year longitudinal survey in Tuscany [69] and the 5 -year national surveillance plan, that included 15 wetland sites across the country [70], gave univocal results indicating that Culex pipiens was the predominant species in all sites, representing more than $50 \%$ of all samples.

It is important to note that, whereas in the tropics WNV transmission may occur all year round, in temperate regions it appears to be limited to the season favorable to the massive development of the vector populations (usually in the late summer). In some cases, it is possible that the potential mosquito vectors become infected in springtime, after biting on migratory birds, and that a few months are necessary for the virus to amplify and spread in a limited area [68]. However, this cannot explain the simultaneous appearance of distinct WNV foci scattered on different regions occurred in Italy in 2008 and 2009. Since infected mosquito may remain able to transmit WNV to other animals even for months after the infected blood meal, it should be considered the possibility that WNF may have overwintered in these temperate regions throughout vertical transmission. This phenomenon has been observed both in the field and in the laboratory, but its real relevance in the epidemiology of WNV is still to be assessed [71-75].

Altogether, the findings from Italian investigations indicate the involvement of $C x$. pipiens as a major WNV vector both in enzootic and epizootic cycles. Since the late 1930's [76, 77], the possibility that $C x$. pipiens in the Paleartic region consists of a species complex or of different biological forms has been and is still debated. The existence of at least two forms with different characteristics related to different environment adaptation [78], namely $C x$. pipiens pipiens (the original rural, mainly ornithophilic) and $C x$. molestus (the urban form, mainly antrhopophilic), is in fact currently accepted [78-82]. Nevertheless the possible existence of further forms, and their role in the transmission of the WNV still need to be deeply investigated.

\section{HOST-PATHOGEN RELATIONSHIP IN WNV INFECTION}

\section{Infection and Clinical Presentation}

WNV infection is a mosquito-borne zoonosis maintained in natural cycles by the involvement of at least 3 different organisms, the virus, an invertebrate vector and a vertebrate host/reservoir [54].

The most common route of WNV transmission to vertebrates is through the bite of an infected mosquito, and a broad range of mammals and non-mammals species like reptiles and amphibians are susceptible to natural or experimental infection with WNV. Some mammals (rodents, rabbits, squirrels) and reptiles (alligators) have been found to develop a sufficient viremia to allow transmission to feeding mosquitoes [83]. Other routes of WNV transmission among humans can be direct blood product contact, organ transplant, transplacentally or via milk ingestion by the newborn. Oral transmission has been experimentally demonstrated in birds, mice and hamsters [84-86].

At a variable time after infection, arguably in temporal association with subsequent viremia, virus gains entry to the central nervous system (CNS). Entry into the CNS represents an extremely important event in both the pathogenesis of disease and the clinical outcome of the host, and is temporally secondary to the spread of virus in the periphery. However, the mechanisms by which WNV enter the CNS are as yet unclear. There is evidence for three major routes: entry via leukocytes, direct entry across the blood brain barrier (BBB) or entry by retrograde axonal transport via the peripheral nervous system [87].

In humans, WNV infections are generally asymptomatic. Most symptomatic patients present a mild flu-like illness (West Nile fever), described in early reports as a self-limited febrile illness characterized by fever, headache, back pain, myalgia and anorexia, sometimes associated with other symptoms like nausea vomiting and diarrhea, and rarely with neurological symptoms [88]. Patients with WNV fever, 
generally recover within a period of 7-10 days. Less than $1 \%$ of documented human infections result in severe neuroinvasive disease, which can be primarily classified into three clinical syndromes: meningitis, encephalitis or acute flaccid paralysis [89]. Clinical features of these syndromes may be present at the same time in the same patient. Additional neurological syndromes include hepatitis [90], myocarditis [91], pancreatitis [92] and hemorragic fever [93]. Advanced age is the main risk factor for the development of encephalitic syndromes [94, 95].

Patients with encephalitis have a higher mortality rate and more severe complications than patients with meningitis [96]. Over the past fifteen years, WNV has shown an increasing tendency to significant, severe and fatal neurological disease in humans, birds and/or horses [89, 97]. Viruses isolated from these recent epidemics and epizootics show high sequence homology ( $\geq 98 \%$ ) with each other and belong to the same clade represented by the New York 1999 isolate, thus suggesting that they all have a common ancestor [98].

Differences in pathogenicity may be related with nucleotide changes in specific regions coding for the premembrane, envelope or nonstructural proteins of the virus $[99,100]$ but no unequivocal association has so far been established with virulence. Recently, a human WNV isolate was obtained, from an asymptomatic blood donor in Italy, and its full genome sequence was compared with earlier WNV strains from horses and humans from Italy and other countries [67]. Interestingly, the Italian isolate showed the Thr249Pro mutation in the helicase domain of the NS3 protein, a trait associated with avian virulence [101]. This mutation has been previously associated with human disease outbreaks [101], although in the Spanish 2007 isolates, it was not associated with increased pathogenicity in mice [102]. The role of this and other mutations in virulence for avian and mammalian species should be further investigated.

WNV has also been shown to establish a persistent infection. In experimentally infected monkeys and hamsters, WNV or viral RNA was find in brain tissues for as long as 5 month [103, 104], and hamsters developed chronic renal infection with WNV shedding in the urine up to 8 months $[105,106]$. Very recently, Murray and colleagues provided evidence that WNV can persist for several years in infected humans, particularly in the presence of chronic clinical symptoms [107]. Consistently with the hamster laboratory model, viral RNA was detected in human urine for at least 6 years after infection, implying a long-term replication of the virus in the kidneys.

As underlined by Gould [108], the findings of WNV persistence for years in the kidneys of convalescent patients could also raise important issues concerning the potential for WNV and other related flaviviruses to be transmitted to mosquitoes by apparently healthy humans or animals, and thus potentially initiate epidemics in new regions of the world.

\section{Innate Immunity}

The integrity of the host immune system is required to prevent severe WNV infection, and in fact neurological disease is remarkably frequent both among the elderly and the immunocompromised subjects, who can exhibit mortality rates higher than $10 \%$ [109].
Overall, humoral immune responses control viral load in the periphery preventing dissemination, whereas T-cell responses are required for the clearance of WNV within the CNS [110]. Several studies remark that both innate and adaptive immunity mechanisms act together in contrasting WNV replication and diffusion [111], and immunity can also be responsible for severe clinical symptoms [87]. As shown in a murine model of infection, WNV reaches the local lymphnodes via infected dendritic cells (DC) and activates events whose balance can lead to either asymptomatic infection or neuroinvasion [112]. If the production of interferon $\alpha$ or $\beta$ (type I IFNs) by infected DCs predominates, local viral replication will be inhibited and adaptive immune response follows WNV contact with antigen-presenting cells $[113,114]$. Conversely, the production of cytokines such as MIF (macrophage migration inhibiting factor) and TNF- $\alpha$ (tumour necrosis factor) may favor viral invasion of the nervous tissues by enhancing the permeability of the blood-brain barrier [115, 116]. At the same time, MIF inhibition was shown to correlate with reduced viral load, inflammation and damage in the brain of WNV infected mice [116], depicting the complexity of phenomena involving the innate immunity regulation.

From studies in blood donors, a strong immune response, primarily associated with expression of IFN- $\gamma$ and IFN- $\alpha$ and high levels of IFN-stimulated chemokines including CCL2 and CXCL10, was found to be involved in the initial control of WNV replication during early infection. Particularly, CXCL10 may be an important host response mediator in the temporal development of innate and adaptive immunity in concert with IFNs [117]. Mice with genetic defects in the cascade of innate immunity components, from IFN to STAT1 through Toll-like receptors 3 and 7, show enhanced tissue viral loads, and are rapidly killed by WNV [118]. However, WNV has evolved countermeasures to limit the efficacy of IFN-mediated immunity, acting largely via nonstructural proteins NS1 and NS2 [119-121]. WNV exhibits resistance to the antiviral effects of IFN in cell culture once infection is established, and this may be the reason for the relatively narrow therapeutic window useful for IFN administration in animal models or humans infected with WNV [114].

Although the cellular immune response in the CNS can itself result in severe injuries to glial cells and neurons, causing irreversible damage, the role of T-cells is essential for the clearance of $\mathrm{WNV}$, and patients with $\mathrm{T}$ cell deficiency are at high risk of neuroinvasive infection and death [122]. Using a mouse infection model [123], agerelated defects in the CD4 and CD8 $\mathrm{T}$ cell response have been proposed to be a key factor for the severity of neurological symptoms and mortality associated with WNV infection in humans older than 50-60 years [124]. The occurrence of both quantitative and qualitative alterations in $\mathrm{T}$ cell immunity suggests possible specific actions in either immunomodulation or treatment for controlling severe WNV infection in elderly.

Much remains however to be understood to modulate the immune response in favor of the host, taking into account the diverse virulence characteristics of different viruses. 


\section{Humoral Immune Response}

The humoral response to any flavivirus infection is important for control of viral infection and dissemination. The role of humoral response in WNV infection is highlighted in mice lacking functional B cells, where WNVinduced disease incidence and severity are increased, but can be prevented by the passive transfer of antibodies from immune wild-type mice $[125,126]$.

Similar to other flaviviruses, also in WNV infection the majority of neutralizing antibodies recognize the structural $\mathrm{E}$ protein, although a subset bind to the $\mathrm{preM} / \mathrm{M}$ protein. Interestingly, antibodies to the NS1 protein are also protective against $\mathrm{WNV}$ in vivo. This protein is a secreted protein that is highly conserved among the flaviviruses. The mechanism(s) of protection are through FCgRs and/or complement, and may depend on the region of NS1 toward which a particular antibody is reactive [127]. Antibody responses to the intracellular proteins NS3 and NS5 have also been observed during WNV infection, although their functional significance remains uncertain [32].

The immunodominant flavivirus protein $\mathrm{E}$ has three structural domains DI, DII and DIII. At least 12 epitopes have been defined and are associated with distinct functions including cell attachment, dimerization, trimerization, and acid-catalyzed fusion. In vitro, the strongest neutralizing activity is exhibited by antibodies against the upper lateral surface of the DIII residue of the protein, that protrudes off the surface of the virion, and protection studies in vivo confirmed this finding [128]. In WNV-infected humans, only $8 \%$ of WNV-specific B-cell clones produced antibodies specific to DIII, whereas almost half of them produced antibody that bound determinants in DII, particularly the fusion loop. Studies of the polyclonal response of WNVinfected horses and humans indicate that the neutralization activity of sera is not dependent upon antibodies directed against the DIII-lateral ridge (lr) epitope [129]. Neutralization of WNV by antibodies is a 'multiple' hit phenomenon requiring engagement by more than a single antibody. For enveloped flaviviruses including WNV, antibody-mediated virus neutralization can occur at several steps in the viral lifecycle, including attachment to receptors on the cell surface, internalization, or fusion within the endosome. Antibodies that coat the virion surface could neutralize directly by blocking receptor engagement or indirectly by inhibiting one of the conformational changes required for virus uncoating and nucleocapsid penetration into the cytoplasm [130].

The amplification of early IgM-dependent neutralizing antibody is critical for the control of severe WNV infections, as demonstrated in experimental studies on C57BL/6 mice. Mice with immune deficiencies that impair antibody priming (lacking C3 or C4 complement components, complement receptors 1 and 2, CD41 T cells, class II MHC expression, or CD40 signaling) also predispose to WNV susceptibility, to decreased antibody responses and survival rates upon WNV infection, and this condition can be prevented with passive transfer of antibodies from immune wild-type mice [125, $126]$.

The humoral response may conversely lead to antibody dependent enhancement (ADE) of infection. ADE occurs when antibody-virus complexes are internalized into cells via FcgRs and replicate to higher extent. This mechanism which has been hypothesized to contribute to the pathogenesis of dengue hemorrhagic fever (DHF) has been observed in WNV infected mice only in experimental settings, but without any significant change in disease phenotype or survival [129]. The conditions that permit the occurrence of $\mathrm{ADE}$ in vivo are very restricted and are modulated in part by complement opsonin C1q binding to individual IgG subclasses [131].

Despite much progress, many questions about the mechanisms of neutralization and the role of the different epitopes of the structural and non-structural proteins of WNV remain unanswered.

\section{VACCINES}

Experimental DNA vaccines have been developed expressing genes encoding the WNV membrane (M) and envelope (E) proteins in eukaryotic expression vectors, and successfully tested in animals and avian species [132-134].

Recombinant WNV proteins have been used in immunization experiments, and recombinant $\mathrm{E}$ protein can be a candidate vaccine to prevent $\mathrm{WN}$ virus infection in animals and humans, as the positive result in mice [135] and non human primates suggest [136].

Attenuated, inactivated and killed viruses are also protective against infection. Inactivated virus immunization can induce stronger humoral responses compared to the DNA plasmid vaccine, but they can present some limitations. In particular, the attenuated vaccines are economic to produce and potent in elicit immune response, but are not suitable for use in the immunocompromised, while the inactivated vaccines, although safer, are rather expensive to produce and less potent.

Recently, a novel class of vaccines against flaviviruses started are under evaluation. They are based on the production of defective viral particles that are unable to spread between normal cells, and are unable to cause disease in vaccinated animals. A proposed single-cycle, encapsidation defective flavivirus vaccine appears to be reasonably cheap to produce, potent, and safe in the immuno-compromised subjects [137].

However, the suitability of vaccine implementation for either human or animal use remains questionable due to the relatively low number and severity of cases worldwide, and the extreme difficulties envisaged in controlling virus spread through the large animal reservoir represented by susceptible avian species.

\section{CONCLUSIONS}

As the other RNA viruses, WNV has a great potential to evolve and mutate in order to exploit environmental opportunities and become more efficient in spreading into new areas. Indeed, in the last decade, WNV has dramatically increased geographic range and has demonstrated a greater pathogenicity to birds and mammalian hosts, including humans. Virological factors have included genetic adaptation for both increased replication in avian hosts and wider range of competent mosquito vectors. Moreover, emergence of WNV strains capable to disseminate more rapidly and with 
greater efficiency at elevated temperatures pointed out the potential importance of temperature as a selective criteria for the emergence of WNV genotypes with increased vectorial capacity.

The pathogenicity in avian host of WNV has been related to the higher virus replication and capability of spreading, and mutations that can affect this character increase the fitness of the virus in a new environment.

The ongoing epidemic that since August 2008 is affecting Northern Italy is an event that can be considered as case study for the better understanding of the mechanism on WNV persistence in an environmental niche.

During this epidemic, some important evidences have been collected: i) virus spreading across a wide area and involvement of human and animal hosts; ii) overwintering of WNV and recrudescence of the outbreak in the following summer season and iii) mutation of the virus towards a higher pathogenicity in the avian species.

With regard to overwintering of the virus, this phenomenon is poorly known. WNV infection in overwintering mosquitoes is rare in nature, and the detection of viremic birds in winter season raises the question of the possibility of persistently infected hosts like bird species or other animals.

Many other questions on the potential persistence and spread of WNV in EU are still unsolved, but data so far support the idea that further knowledge on the immune response of the avian hosts, vector fitness and development of control strategies including vaccination can provide better understanding of the kinetics of WNV infection.

\section{ACKNOWLEDGEMENTS}

Funding for this work was provided by EU FP7 coordinating action 'ArboZooNet' International Network for Capacity Building for the Control of Emerging Viral Vector Borne Zoonotic Diseases (GAN 211757).

\section{REFERENCES}

[1] Murgue B, Murri S, Triki H, Deubel V, Zeller HG. West Nile in the Mediterranean basin: 1950-2000. Ann N Y Acad Sci 2001; 951: $117-26$.

[2] Smithburn KC, Hughes TP, Burke AW, Paul JH. A neurotropic virus isolated from the blood of a native of Uganda. Am J Trop Med Hyg 1940; 20: 471-92.

[3] Weinberger M, Pitlik SD, Gandacu D, et al. West Nile fever outbreak, Israel, 2000: epidemiologic aspects. Emerg Infect Dis 2001; 7: 686-91.

[4] George S, Gourie-Devi M, Rao JA, Prasad SR, Pavri KM. Isolation of West Nile Fever from the brains of children who had died of encephalitis. Bull Word Health Org 1984; 62: 879-82.

[5] Hubálek Z, Halouzka J. West Nile fever - a reemerging mosquitoborne viral disease in Europe. Emerg Infect Dis 1999; 5: 643-50.

[6] Jia XY, Briese T, Jordan I, et al. Genetic analysis of West Nile New York 1999 encephalitis virus. Lancet 1999; 354: 1971-2.

[7] Lanciotti RS, Roehrig JT, Deubel V, et al. Origin of the West Nile virus responsible for an outbreak of encephalitis in the northeastern United States. Science 1999; 286: 2333-7.

[8] Lindenbach BD, Rice CM. In: Knipe DM, Howley PM, et al., Eds. Flaviviridae: the viruses and their replication. Fields Virology, $4^{\text {th }}$ ed. Philadelphia, Pennsylvania: Lippincott Williams and Wilkins 2001; vol. 1: pp. 991-1041.

[9] Deubel V, Fiette L, Gounon P, et al. Variations in biological features of West Nile viruses. Ann N Y Acad Sci 2001; 951: 195206
[10] Mukhopadhyay S, Kuhn RJ, Rossmann MG. A structural perspective of the flavivirus life cycle. Nat Rev Microbiol 2005; 3 : 13-22.

[11] Sampath A, Padmanabhan R. Molecular targets for flavivirus drug discovery. Antiviral Res 2009; 81: 6-15.

[12] Berthet FX, Zeller HG, Drouet MT, Rauzier J, Digoutte JP, Deubel V. Extensive nucleotide changes and deletions within the envelope glycoprotein gene of Euro-African West Nile viruses. J Gen Virol 1997; 78: 2293-7.

[13] Lanciotti RS, Ebel GD, Deubel V, et al. Complete genome sequences and phylogenetic analysis of West Nile virus strains isolated from the United States, Europe and the Middle East. Virology 2002; 298: 96-105.

[14] Charrel RN, Brault AC, Gallian P, et al. Evolutionary relationship between Old World West Nile virus strains. Evidence for viral gene flow between Africa, the Middle East, and Europe. Virology 2003; 315: 381-8.

[15] Savage HM, Ceianu C, Nicolescu G, et al. Entomologic and avian investigations of an epidemic of West Nile fever in Romania in 1996, with serological and molecular characterization of a virus isolate from mosquitoes. Am J Trop Med Hyg 1999; 61: 600-11.

[16] Scherret JH, Poidinger M, Mackenzie JS, et al. The relationships between West Nile and Kunjin viruses. Emerg Infect Dis 2001; 7: 697-705

[17] Monaco F, Lelli R, Teodori L, et al. Re-Emergence of West Nile Virus in Italy. Zoonoses Public Health 2009 [Epub ahead of print].

[18] Barzon L, Squarzon L, Cattai M, et al. West Nile virus infection in Veneto region, Italy, 2008-2009. Euro Surveill 2009; 14: pii=19289. Available from: http://www.eurosurveillance.org/View Article. aspx?ArticleId $=19289$

[19] Zeller HG, Schuffenecker I. West Nile virus: an overview of its spread in Europe and the Mediterranean basin in contrast to its spread in the Americas. Eur J Clin Microbiol Infect Dis 2004; 23: 147-56.

[20] Umrigar MD, Pavri KM. Comparative biological studies on Indian strains of West Nile virus isolated from different sources. Indian J Med Res 1977; 65: 596-602.

[21] Lvov DK, Butenko AM, Gromashevsky VL, et al. West Nile virus and other zoonotic viruses in Russia: examples of emergingreemerging situations. Arch Virol Suppl 2004; 18: 85-96.

[22] Bakonyi T, Hubalek Z, Rudolf I, Nowotny N. Novel flavivirus or new lineage of West Nile virus, central Europe. Emerg Infect Dis 2005; 11: 225-31.

[23] Bondre VP, Jadi RS, Mishra AC, Yergolkar PN, Arankalle VA. West Nile virus isolates from India: evidence for a distinct genetic lineage. J Gen Virol 2007; 88: 875-84.

[24] Dauphin G, Zientara S. West Nile virus: recent trends in diagnosis and vaccine development. Vaccine 2007; 25: 5563-76.

[25] Castillo-Olivares J, Wood J. West Nile virus infection of horses. Vet Res 2004; 35: 467-83.

[26] Innis BL, Nisalak A, Nimmannitya S, et al. An enzyme-linked immunosorbent assay to characterize dengue infections where dengue and Japanese encephalitis co-circulate. Am J Trop Med Hyg 1989; 40: 418-27.

[27] Kuno G, Gubler DJ, Oliver A. Use of 'original antigenic sin' theory to determine the serotypes of previous dengue infections. Trans $\mathrm{R}$ Soc Trop Med Hyg 1993; 87: 103-5.

[28] Lanciotti RS, Kerst AJ, Nasci RS, et al. Rapid detection of west nile virus from human clinical specimens, field-collected mosquitoes, and avian samples by a TaqMan reverse transcriptasePCR assay. J Clin Microbiol 2000; 38: 4066-71.

[29] Herrmann S, Leshem B, Landes S, Rager-Zisman B, Marks RS. Chemiluminescent optical fiber immunosensor for the detection of anti-West Nile virus IgG. Talanta 2005; 66: 6-14.

[30] Holmes DA, Purdy DE, Chao DY, Noga AJ, Chang GJ. Comparative analysis of immunoglobulin M (IgM) capture enzyme-linked immunosorbent assay using virus-like particles or virus-infected mouse brain antigens to detect IgM antibody in sera from patients with evident flaviviral infections. J Clin Microbiol 2005; 43: 3227-36.

[31] Hukkanen RR, Liggitt HD, Kelley ST, et al. Comparison of commercially available and novel West Nile virus immunoassays for detection of seroconversion in pig-tailed macaques (Macaca nemestrina). Comp Med 2006; 56: 46-54.

[32] Wong SJ, Boyle RH, Demarest VL, et al. Immunoassay targeting nonstructural protein 5 to differentiate West Nile virus infection 
from dengue and St. Louis encephalitis virus infections and from flavivirus vaccination. J Clin Microbiol 2003; 41: 4217-23.

[33] Martin DA, Biggerstaff BJ, Allen B, Johnson AJ, Lanciotti RS, Roehrig JT. Use of immunoglobulin $M$ cross-reactions in differential diagnosis of human flaviviral encephalitis infections in the United States. Clin Diagn Lab Immunol 2002; 9: 544-549.

[34] Niedrig M, Sonnenberg K, Steinhagen K, Paweska JT. Comparison of ELISA and immunoassays for measurement of IgG and IgM antibody to West Nile virus in human sera against virus neutralisation. J Virol Methods 2007; 139: 103-5.

[35] Oceguera LF, Patiris PJ, Chiles RE, Busch MP, Tobler LH, Hanson CV. Flavivirus serology by Western blot analysis. Am J Trop Med Hyg 2007; 77: 159-63.

[36] Loroño-Pino MA, Farfan-Ale JA, Blitvich BJ, Beebe JL, Jarman RG, Beaty BJ. Evaluation of an epitope-blocking enzyme-linked immunosorbent assay for the diagnosis of West Nile virus infections in humans. Clin Vaccine Immunol 2009; 16: 749-55.

[37] Jibin Z, Xiumei L, Hongping W, et al. Production and characterization of monoclonal antibodies to nucleoprotein of Marburg virus. Hybridoma 2008; 27: 423-9.

[38] Deyev SM, Lebedenko EN. Multivalency: the hallmark of antibodies used for optimization of tumor targeting by design. Bioessays 2008; 30: 904-18.

[39] Phipps LP, Gough RE, Ceeraz V, Cox WJ, Brown IH. Detection of West Nile virus in the tissues of specific pathogen free chickens and serological response to laboratory infection: a comparative study. Avian Pathol 2007; 36: 301-5.

[40] Dyer J, Chisenhall DM, Mores CN. A multiplexed TaqMan assay for the detection of arthropod-borne flaviviruses. J Virol Methods 2007; 145: 9-13.

[41] Moureau G, Temmam S, Gonzalez JP, Charrel RN, Grard G, de Lamballerie X. A real-time RT-PCR method for the universal detection and identification of flaviviruses. Vector Borne Zoonotic Dis 2007; 7: 467-77.

[42] Ostlund EN, Crom RL, Pedersen DD, Johnson DJ, Williams WO, Schmitt BJ. Equine West Nile encephalitis, United States. Emerg Infect Dis 2001; 7: 665-9.

[43] Chao DY, Davis BS, Chang GJ. Development of multiplex realtime reverse transcriptase PCR assays for detecting eight medically important flaviviruses in mosquitoes. J Clin Microbiol 2007; 45: 584-9.

[44] Zhang W, Wu J, Li Y, Li F, Njoo H. Rapid and accurate in vitro assays for detection of West Nile virus in blood and tissues. Transfus Med Rev 2009; 23: 146-54.

[45] Centers for Disease Control and Prevention. West Nile Virus infections in organ transplant recipients - New York and Pennsylvania, August-September, 2005. Morb Mortal Wkly Rep 2005; 54: 1021-3.

[46] Centers for Disease Control and Prevention. West Nile virus transmission through blood transfusion - South Dakota, 2006. Morb Mortal Wkly Rep 2007; 56: 76-9.

[47] Stramer SL, Custer B, Busch MP, Dodd RY. Strategies for testing blood donors for West Nile virus. Transfusion 2006; 46(12): 20367.

[48] Naze F, Le Roux K, Schuffenecker I, et al. Simultaneous detection and quantitation of Chikungunya, dengue and West Nile viruses by multiplex RT-PCR assays and dengue virus typing using high resolution melting. J Virol Methods 2009; 162: 1-7.

[49] Chisenhall DM, Vitek CJ, Richards SL, Mores CN. A method to increase efficiency in testing pooled field-collected mosquitoes. J Am Mosq Control Assoc 2008; 24: 311-4.

[50] Ulloa A, Ferguson HH, Méndez-Sánchez JD, et al. West Nile virus activity in mosquitoes and domestic animals in Chiapas, México. Vector Borne Zoonotic Dis 2009; 9: 555-60.

[51] Maher-Sturgess SL, Forrester NL, Wayper PJ, et al. Universal primers that amplify RNA from all three flavivirus subgroups. Virol J 2008; 5: 16.

[52] Scaramozzino N, Crance J-M, Jouan A, DeBriel DA, Stoll F, Garin D. Comparison of Flavivirus universal primer pairs and development of a rapid, highly sensitive heminested reverse transcription-PCR assay for detection of flaviviruses targeted to a conserved region of the NS5 gene sequences. J Clin Microbiol 2001; 39: 1922-7.

[53] Rappole JH, Derrickson SR, Hubálek Z. Migratory birds and spread of West Nile virus in the Western Hemisphere. Emerg Infect Dis $2000 ; 6: 319-28$.
[54] Campbell GL, Marfin AA, Lanciotti RS, Gubler DJ. West Nile virus. Lancet Infect Dis 2002; 2: 519-29.

[55] Higgs S, Snow K, Gould EA. The potential for West Nile virus to establish outside of its natural range: a consideration of potential mosquito vectors in the United Kingdom. Trans R Soc Trop Med Hyg 2004; 98: 82-7.

[56] Crook PD, Crowcroft NS, Brown DW. West Nile virus and the threat to the UK. Commun Dis Public Health 2002; 5: 138-43.

[57] Campbell GL, Ceianu CS, Savage HM. Epidemic West Nile encephalitis in Romania: waiting for history to repeat itself. Ann N Y Acad Sci 2001; 951: 94-101.

[58] Ceianu CS, Ungureanu A, Nicolescu G, et al. West nile virus surveillance in Romania: 1997-2000. Viral Immunol 2001; 14 251-62.

[59] Bernard K, Maffei G, Jones S, et al. West Nile virus infection in birds and mosquitoes, New York State, 2000. Emerg Infect Dis 2001; 7: 679-85.

[60] Sardelis MR, Turell MJ, Dohm DJ, O'Guinn ML. Vector competence of selected North American Culex and Coquillettidia mosquitoes for West Nile virus. Emerg Infect Dis 2001; 7: 101822.

[61] Sardelis MR, Turell MJ, Ochlerotatus J. Japonicus in Frederick County, Maryland: discovery, distribution, and vector competence for West Nile virus. J Am Mosq Control Assoc 2001; 17: 137-41.

[62] Turell MJ, O'Guinn ML, Dohm DJ, Jones JW. Vector competence of North American mosquitoes (Diptera: Culicidae) for West Nile virus. J Med Entomol 2001; 38: 130-4.

[63] Turell MJ, Sardelis MR, Dohm DJ, O'Guinn ML. Potential North American vectors of West Nile virus. Ann N Y Acad Sci 2001; 951:317-24.

[64] Turell MJ, Dohm DJ, Sardelis MR, Oguinn ML, Andreadis TG, Blow JA. An update on the potential of north American mosquitoes (Diptera: Culicidae) to transmit West Nile Virus. J Med Entomol 2005; 42: 57-62.

[65] Goddard LB, Roth AE, Reisen WK, Scott TW. Vector competence of California mosquitoes for West Nile virus. Emerg Infect Dis 2002; 8: 1385-91.

[66] Rizzo C, Vescio F, Declich S, et al. West Nile virus transmission with human cases in Italy, August - September 2009. Euro Surveill 2009; 14. pii: 19353. Available from: http://www.eurosurveillance. org/ViewArticle.aspx?ArticleId=19353

[67] Barzon L, Franchin E, Squarzon L, et al. Genome sequence analysis of the first human West Nile virus isolated in Italy in 2009. Euro Surveill 2009; 14: pii=19384. Available online: http://www. eurosurveillance.org/ViewArticle. aspx?ArticleId=19384

[68] Autorino GL, Battisti A, Deubel V, et al. West Nile virus epidemic in horses, Tuscany region, Italy. Emerg Infect Dis 2002; 8: 1372-8.

[69] Romi R, Pontuale G, Ciufolini MG, et al. Potential vectors of West Nile Virus following an equine disease outbreak in Italy. Med Vet Ent 2004; 18: 14-9.

[70] Toma L, Cipriani M, Romi R, Goffredo M, Lelli R. First report on entomological field activity for the surveillance of west Nile disease in Italy. Vet Ital 2008; 44: 483-96.

[71] Baqar S, Hayes CG, Murphy JR, Watts DM. Vertical transmission of West Nile virus by Culex and Aedes species mosquitoes. Am J Trop Med Hyg 1993; 48: 757-62.

[72] Miller BR, Nasci RS, Godsey MS, et al. First field evidence for natural vertical transmission of West Nile virus in Culex univittatus complex mosquitoes from Rift Valley province, Kenya. Am J Trop Med Hyg 2000; 62: 240-6.

[73] Mishra AC, Mourya DT. Transovarial transmission of West Nile virus in Culex vishnui mosquito. Indian J Med Res 2001; 114: 2124.

[74] Dohm DJ, Sardelis MR, Turell MJ. Experimental vertical transmission of West Nile virus by Culex pipiens (Diptera: Culicidae). J Med Entomol 2002; 39: 640-4.

[75] Goddard LB, Roth AE, Reisen WK, Scott TW. Vertical transmission of West Nile Virus by three California Culex (Diptera: Culicidae) species. J Med Entomol 2003; 40: 743-6.

[76] La Face L. Osservazioni sul C. pipiens autogenicus. Rendiconti Ist San Pub 1938; 1: 669-78.

[77] La Face L. Osservazioni sulla biologia del complesso "Culex pipiens". Parassitologia 1962; 4: 155-8.

[78] Vinogradova EB. Culex pipiens pipiens mosquitoes: taxonomy, distribution, ecology, physiology, genetics, applied importance and 
control. Chp 1. Golovatch SI, Ed. Sofia, Bulgaria: PENSOFT Publishers 2000; pp. 4-45.

[79] Vinogradova EB, Shaikevich EV. Morphometric, physiological and molecular characteristics of underground populations of the urban mosquito Culex pipiens Linnaeus f. Molestus Forskål (Diptera: Culicidae) from several areas of Russia. Eur Mosq Bull 2007; 23: 25-30.

[80] Weitzel T, Collado A, Jöst A, Pietsch K, Storch V, Becker N. Genetic differentiation of populations within the culex pipiens complex and phylogeny of related species. J Am Mosq Control Assoc 2009; 25: 6-17.

[81] Bahnck CM, Fonseca DM. Rapid assay to identify the two genetic forms of Culex (Culex) pipiens L. (Diptera: Culicidae) and hybrid populations. Am J Trop Med Hyg 2006; 75: 251-5.

[82] Kent RJ, Harrington LC, Norris DE. Genetic differences between Culex pipiens f.molestus and Culex pipiens pipiens (Diptera: Culicidae) in New York. Med Entomol 2007; 44: 50-9.

[83] Bowen RA, Nemeth NM. Experimental infections with West Nile virus. Curr Opin Infect Dis 2007; 20: 293-7.

[84] Komar N, Langevin S, Hinten S, et al. Experimental infection of North American birds with the New York 1999 strain of West Nile virus. Emerg Infect Dis 2003; 9: 311-22.

[85] Odelola HA, Oduye OO. West Nile virus infection of adult mice by oral route. Arch Virol 1977; 54: 251-3.

[86] Sbrana E, Tonry JH, Xiao SY, da Rosa AP, Higgs S, Tesh RB. Oral transmission of West Nile virus in a hamster model. Am J Trop Med Hyg 2005; 72: 325-9.

[87] King NJ, Getts DR, Getts MT, Rana S, Shrestha B, Kesson AM. Immunopathology of flavivirus infections. Immunol Cell Biol 2007; 85: 33-42.

[88] Mostashari F, Bunning ML, Kitsutani PT, et al. Epidemic West Nile encephalitis, New York, 1999: results of a household-based seroepidemiological survey. Lancet 2001; 358: 261-4.

[89] Kramer LD, Li J, Shi PY. West Nile virus. Lancet Neurol 2007; 6: 171-81.

[90] Georges AJ, Lesbordes JL, Georges-Courbot MC, Meunier DMY, Gonzalez JP. Fatal hepatitis from West Nile virus. Ann Inst Pasteur Virol 1987: 138: 237-44.

[91] Albagali C, Chaimoff R. A case of West Nile myocarditis. Harefuah 1959; 57: 274-6.

[92] Perelman A, Stern J. Acute pancreatitis in West Nile fever. Am J Trop Med Hyg 1974; 23: 1150-2.

[93] Paddock CD, Nicholson WL, Bhatnagar J, et al. Fatal hemorrhagic fever caused by West Nile virus in the United States. Clin Infect Dis 2006; 42: 1527-35.

[94] Hayes EB, Komar N, Nasci RS, Montgomery SP, O'Leary DR, Campbell GL. Epidemiology and transmission dynamics of West Nile virus disease. Emerg Infect Dis 2005; 11: 1167-73.

[95] Mazurek JM, Winpisinger K, Mattson BJ, Duffy R, Moolenaar RL. The epidemiology and early clinical features of West Nile virus infection. Am J Emerg Med 2005; 23: 536-43.

[96] Bode AV, Sejvar JJ, Pape WJ, et al. West Nile virus disease: a descriptive study of 228 patients hospitalized in a 4-county region of Colorado in 2003. Clin Infect Dis 2006; 42: 1234-40.

[97] Artsob H, Gubler DJ, Enria DA, et al. West Nile Virus in the new world: trends in the spread and proliferation of West nile virus in the western hemisphere. Zoonoses Public Health 2009; 56: 357-69.

[98] Gubler DJ. The continuing spreading of West Nile Virus in the western hemisphere. Clin Infect Dis 2007; 45: 1039-46.

[99] Beasley DW, Davis CT, Whiteman M, Granwehr B, Kinney RM, Barrett AD. Molecular determinants of virulence of West Nile virus in North America. Arch Virol 2004; 18(Suppl): 35-41.

[100] Davis CT, Beasley DW, Guzman H, et al. Emergence of attenuated West Nile virus variants in Texas, 2003. Virology 2004; 330: 34250 .

[101] Brault AC, Huang CY, Langevin SA, et al. A single positively selected West Nile viral mutation confers increased virogenesis in American crows. Nat Genet 2007; 39: 1162-6.

[102] Sotelo E, Fernandez-Pinero J, Llorente F, et al. Characterization of West Nile virus isolates from Spain: new insights into the distinct West Nile virus eco-epidemiology in the Western Mediterranean. Virology 2009; 13. doi:10.1016/j.virol. 2009.09.013.

[103] Pogodina VV, Frolova MP, Malenko GV, et al. Study on West Nile virus persistence in monkeys. Arch Virol 1983; 75: 71-86.
[104] Siddharthan V, Wang H, Motter NE, et al. Persistent West Nile virus associated with a neurological sequela in hamsters identified by motor unit number estimation. J Virol 2009; 83: 4251-61.

[105] Tesh RB, Siirin M, Guzman H, et al. Persistent West Nile virus infection in the golden hamster: studies on its mechanism and possible implications for other flavivirus infections. J Infect Dis 2005; 192: 287-95.

[106] Tonry JH, Xiao S-Y, Siirin M, Chen H, Travassos APA, Tesh RB. Persistent shedding of West Nile virus in the urine of experimentally infected hamsters. Am J Trop Med Hyg 2005; 72: 320-4.

[107] Murray K, Walker C, Herrington E, et al. Persistent infection with West Nile virus years after initial infection. J Infect Dis 2010; 201: $2-4$.

[108] Gould EA. West nile virus: don't underestimate its persistence. J Infect Dis 2010; 201: 1 .

[109] Komar N. West Nile viral encephalitis. Rev Sci Tech 2000; 19: 166-76.

[110] Shrestha B, Ng T, Chu HJ, Noll M, Diamond MS, Komar N. West Nile viral encephalitis. The relative contribution of antibody and CD8+ $\mathrm{T}$ cells to vaccine immunity against West Nile encephalitis virus. Vaccine 2008; 26: 2020-33.

[111] Diamond MS, Shrestha B, Mehlhop E, Sitati E, Engle M. Innate and adaptive immune responses determine protection against disseminated infection by West Nile encephalitis virus. Viral Immunol 2003; 16: 259-78.

[112] Byrne SN, Halliday GM, Johnston LJ, King NJ. Interleukin-1beta but not tumor necrosis factor is involved in West Nile virusinduced Langerhans cell migration from the skin in C57BL/6 mice. J Invest Dermatol 2001; 117: 702-9.

[113] Scholle F, Mason PW. West Nile virus replication interferes with both poly (I:C)-induced interferon gene transcription and response to interferon treatment. Virology 2005; 342: 77-87.

[114] Liu WJ, Wang XJ, Clark DC, Lobigs M, Hall RA, Khromykh AA. A single aminoacid substitution in the West Nile virus nonstructural protein NS2A disables its ability to inhibit alpha/beta interferon induction and attenuates virus virulence in mice. J Virol 2006; 80: 2396-404.

[115] Arjona A, Foellmer HG, Town T, et al. Abrogation of macrophage migration inhibitory factor decreases West Nile virus lethality by limiting viral neuroinvasion. J Clin Invest 2007a; 117: 3059-66.

[116] Arjona A, Ledizet M, Anthony K, et al. West Nile virus envelope protein inhibits dsRNA-induced innate immune responses. J Immunol 2007b; 179: 8403-9.

[117] Tobler LH, Cameron MJ, Lanteri MC, et al. Interferon and interferon-induced chemokine expression is associated with control of acute viremia in West Nile virus-infected blood donors. J Infect Dis 2008; 198: 979-83.

[118] Daffis S, Samuel MA, Suthar MS, Gale M Jr, Diamond MS. Tolllike receptor 3 has a protective role against West Nile virus infection. J Virol 2008; 82: 10349-58.

[119] Keller BC, Johnson CL, Erickson AK, Gale M Jr. Innate immune evasion by hepatitis $\mathrm{C}$ virus and West Nile virus. Cytokine Growth Factor Rev 2007; 18: 535-44.

[120] Jiang Z, Mak TW, Sen G, Li X. Toll-like receptor 3-mediated activation of NF-kappaB and IRF3 diverges at Toll-IL-1 receptor domain-containing adapter inducing IFN-beta. Proc Natl Acad Sci USA 2004; 101: 3533-8.

[121] Wilson JR, de Sessions PF, Leon MA, Scholle F. West Nile virus nonstructural protein 1 inhibits TLR3 signal transduction. J Virol 2008; 82: 8262-71.

[122] Murray K, Baraniuk S, Resnick M, et al. Risk factors for encephalitis and death from West Nile virus infection. Epidemiol Infect 2006; 134: 1325-32.

[123] Brien JD, Uhrlaub JL, Hirsch A, Wiley CA, Nikolich-Zugich J. Key role of $\mathrm{T}$ cell defects in age-related vulnerability to West Nile virus. J Exp Med 2009; 206(12): 2735-45.

[124] Kong KF, Delroux K, Wang X, et al. Dysregulation of TLR3 impairs the innate immune response to West Nile virus in the elderly. J Virol 2008; 82: 7613-23.

[125] Sitati E, Diamond MS. CD41 T cell responses are required for clearance of West Nile Virus from the central nervous system. J Virol 2006; 80: 12060-9.

[126] Sitati E, McCandless EE, Klein RS, Diamond MS. CD40-CD40 ligand interactions promote trafficking of CD81 $\mathrm{T}$ cells into the 
brain and protection against West Nile virus encephalitis. J Virol 2007; 81: 9801-11.

[127] Chung KM, Nybakken GE, Thompson BS, et al. Antibodies against West Nile Virus nonstructural protein NS1 prevent lethal infection through $\mathrm{Fc}$ gamma receptor-dependent and -independent mechanisms. J Virol 2006; 80: 1340-51.

[128] Oliphant T, Engle M, Nybakken GE, et al. Development of a humanized monoclonal antibody with therapeutic potential against West Nile virus. Nat Med 2005; 11: 522-30.

[129] Diamond MS, Pierson TC, Fremont DH, et al. The structural immunology of antibody protection against West Nile virus. Immunol Rev 2008; 225: 212-25.

[130] Klasse PJ, Sattentau QJ. Mechanisms of virus neutralization by antibody. Curr Top Microbiol Immunol 2001; 260: 87-108.

[131] Mehlhop E, Ansarah-Sobrinho C, Johnson S, et al. Complement protein $\mathrm{Clq}$ inhibits antibody-dependent enhancement of flavivirus infection in an IgG subclass-specific manner. Cell Host Microbe 2007; 2 : 417-26.

[132] Davis BS, Chang GJ, Cropp B, et al. West Nile virus recombinant DNA vaccine protects mouse and horse from virus challenge and expresses in vitro a noninfectious recombinant antigen that can be used in enzyme-linked immunosorbent assays. J Virol 2001; 75: 4040-7.

[133] Turell M, Bunning M, Ludwig G, et al. DNA vaccine for West Nile virus infection in fish crows (Corvus ossifragus). Emerg Infect Dis 2003; 9: 1077-81.

[134] Chang GJJ, Davis BS, Stringfield C, Lutz C. Prospective immunization of the endangered California condors (Gymnogyps californianus) protects this species from lethal West Nile virus infection. Vaccine 2007; 25: 2325-30.

[135] Lieberman MM, Clements DE, Ogata S, et al. Preparation and immunogenic properties of a recombinant West Nile subunit vaccine. Vaccine 2007; 25: 414-23.

[136] Lieberman MM, Nerurkar VR, Luo $\mathrm{H}$, et al. Immunogenicity and protective efficacy of a recombinant subunit West Nile virus vaccine in rhesus monkeys. Clin Vaccine Immunol 2009; 16: 13327.

[137] Widman DG, Frolov I, Mason PW. Third-generation flavivirus vaccines based on single-cycle, encapsidation-defective viruses. Adv Virus Res 2008; 72: 77-126.

(C) Monini et al.; Licensee Bentham Open.

This is an open access article licensed under the terms of the Creative Commons Attribution Non-Commercial License (http: //creativecommons.org/licenses/by-nc/ $3.0 /$ ) which permits unrestricted, non-commercial use, distribution and reproduction in any medium, provided the work is properly cited. 